\title{
The effects of antiepileptic drugs on the growth of glioblastoma cell lines
}

\author{
Ching-Yi Lee ${ }^{1} \cdot$ Hung-Yi Lai $^{1} \cdot$ Angela Chiu $^{1} \cdot$ She-Hung Chan ${ }^{1}$. \\ Ling-Ping Hsiao ${ }^{1} \cdot$ Shih-Tseng Lee ${ }^{1}$
}

Received: 17 September 2015/Accepted: 30 December 2015/Published online: 13 January 2016

(c) The Author(s) 2016. This article is published with open access at Springerlink.com

\begin{abstract}
To determine the effects of antiepileptic drug compounds on glioblastoma cellular growth, we exposed glioblastoma cell lines to select antiepileptic drugs. The effects of selected antiepileptic drugs on glioblastoma cells were measured by MTT assay. For compounds showing significant inhibition, cell cycle analysis was performed. Statistical analysis was performed using SPSS. The antiepileptic compounds selected for screening included carbamazepine, ethosuximide, gabapentin, lamotrigine, levetiracetam, magnesium sulfate, oxcarbazepine, phenytoin, primidone, tiagabine, topiramate, valproic acid, and vigabatrin. Dexamethasone and temozolomide were used as a negative and positive control respectively. Our results showed temozolomide and oxcarbazepine significantly inhibited glioblastoma cell growth and reached $\mathrm{IC}_{50}$ at therapeutic concentrations. The other antiepileptic drugs screened were unable to reach $\mathrm{IC}_{50}$ at therapeutic concentrations. The metabolites of oxcarbazepine were also unable to reach $\mathrm{IC}_{50}$. Dexamethasone, ethosuximide, levetiracetam, and vigabatrin showed some growth enhancement though they did not reach statistical significance. The growth enhancement effects of ethosuximide, levetiracetam, and vigabatrin found in the study may indicate that these compounds should not be used for prophylaxis or short term treatment of epilepsy in glioblastoma. While valproic acid and oxcarbazepine were effective, the required dose of valproic acid was far above that used for the treatment of epilepsy and the metabolites
\end{abstract}

Shih-Tseng Lee

yun0710@adm.cgmh.org.tw

1 Department of Neurosurgery, Chang-Gung Memorial Hospital, Chang-Gung University College of Medicine, 5 Fu-Shing Street, 333, Kweishan, Taoyuan, Taiwan of oxcarbazepine failed to reach significant growth inhibition ruling out the use of oral oxcarbazepine or valproic acid as monotherapy in glioblastoma. The possibility of using these compounds as local treatment is a future area of study.

Keywords Glioblastoma - Antiepileptic .

Oxcarbazepine - Valproic acid · Temozolomide

\section{Introduction}

Gliomas represent approximately $31 \%$ of all primary brain and central nervous system (CNS) tumors with glioblastoma multiforme (GBM) accounting for almost $17 \%$ of all tumors [1] Long term survivors of GBM are rare with a median survival of less than 1 year being typical and a 5 year survival rate of less than $5 \%$ [1-5].

Treatment of high grade gliomas typically includes surgical excision followed by chemotherapy and symptom management. GBM is treated with temozolomide (TMZ) given concomitantly with radiation therapy (RT) to increase efficacy and then continued as adjuvant treatment for 6 to 12 months afterwards [4, 6-14].

Epileptic seizures are the presenting symptom of intracranial lesions $30-50 \%$ of the time $[15,16] .10-30 \%$ of patients who are seizure free at diagnosis develop seizures at some point throughout their disease progression [5, $16,17]$ Patients that develop seizures are treated with antiepileptic drugs (AEDs) and some physicians may use AEDs prophylactically to prevent possible seizure complications after the diagnosis of cranial lesions or after surgery. Since the pathophysiology behind these seizures is complex, many patients are likely to require multiple AEDs in combination. 
Valproic acid (VPA) is used for the treatment tumor associated epilepsy (TAE) due to studies showing VPA to have anticancer properties $[4,5,9,11,12,15-24]$. In our previous study to examine the correlation between the use of VPA in patients diagnosed with GBM and patient survival, the results concluded that VPA, at serum concentrations used for the treatment of seizures $(50-100 \mathrm{ug} / \mathrm{ml})$, may be beneficial and lead to a better prognosis in the treatment of GBM when combined with total resection of tumors and post-operative chemotherapy [25]. While some studies examine VPA as a possible anti-cancer agent and others examine the efficacy of AEDs for seizure reduction in glioma and GBM, few look at the direct possible anticancer effects of AEDs.

This cell culture study aims to address the following points: 1) if VPA alone at the clinical therapeutic level used for epilepsy treatment in patients has equivalent anticancer effects in cell cultures, 2) at what concentration does VPA alone demonstrate anti-cancer effects, and 3) what other AEDs influence the growth of glioma/GBM cells when used at the targeted therapeutic levels for seizure control. Identifying the optimal use of VPA and determining the effects of other AEDs on glioma/GBM cells will allow for enhanced therapy which is important in patients with GBM who have poor survival even when given optimal therapy.

\section{Materials and methods}

\section{Cell line selection and cell culture}

Human glioma cell lines U-87 MG and T98G [American type culture collection (ATCC), Manassas, VA] were used in this study. The cell line U87 MG, used in multiple studies, represents typical glioblastoma [26-28] The T98 cell line represents resistant glioblastoma due to TMZ resistance [29] Cells were cultured in Eagle's minimal essential medium (EMEM) supplemented with $10 \%$ Fetal bovine serum (FBS), and $1 \%$ antibiotic antimycotic solution and placed in a standard humidified incubator at $37{ }^{\circ} \mathrm{C}$ and $5 \% \mathrm{CO}_{2} / 95 \%$ air atmosphere.

\section{Drug compound selection}

Drugs compounds were chosen based on the antiepileptic drugs available on the Chang Gung Memorial Hospital formulary. The compounds used are listed in Table 1 . Temozolomide acts as a positive control showing growth inhibition. Dexamethasone (DEX) acts as a negative control to show growth enhancement in GBM [30, 31] Licarbazepine (R-(-)-10-hydroxy- 10,11-dihydro- carbamazepine or monohydroxycarbamazepine (R-(-)-MHC)) and eslicarbazepine (S-(+)-10-hydroxy- 10,11-dihydrocarbamazepine or monohydroxycarbamazepine (S- $(+)-$ MHC)), metabolites of the prodrug $\mathrm{OXC}$, were added to the compounds selected after preliminary data indicated that OXC induced significant growth inhibition.

\section{Reagents}

EMEM powder and antibiotic/antimycotic solution were obtained from Gibco, Grand Island, NY. FBS and phosphate buffered saline (PBS) were obtained from Hyclone through Thermo Scientific. Dimethyl sulfoxide (DMSO), ethanol (99 \%) (EtOH), TMZ, DEX, VPA, carbamazepine (CBZ), ethosuximide (ESX), gabapentin (GBP), lamotrigine (LTG), levetiracetam (LEV), magnesium sulfate $\left(\mathrm{MgSO}_{4}\right)$, oxcarbazepine (OXC), phenytoin (5, 5 diphenylhydantoin) (PHT), primidone (PRM), tiagabine (TGB), topiramate (TPM), and vigabatrin (VBT) were obtained from Sigma-Aldrich, St. Louis, MO. R-(-)-MHC and S-(+)-MHC were obtained from Santa Cruz, Dallas, TX.

\section{Dose determination}

The drug concentration ranges chosen for this study were taken from estimated drug plasma levels reported to be found in patients with adjustments for protein binding as needed [32-35]. The range was based on the minimum reported effective plasma level and the maximum reported level found in patients [35-38]. Toxic plasma levels were determined from Micromedex and other reports [35-38]. The drug concentration range for VPA was extended to toxic levels to ensure that $\mathrm{IC}_{50}$ for VPA would be obtained due to reports of VPA as an anti-cancer agent (Table 1).

\section{Experimental procedure}

Cells were collected and seeded in 24-well plates at a density of $1 \times 10^{4}$ cells/well (U-87 MG) and $5 \times 10^{3}$ cells/well (T98G) after optimization at the beginning of the experiments. After $24 \mathrm{~h}$, drug was added to each well to reach the dosing concentrations listed in Table 1. The treated cells were incubated for $72 \mathrm{~h}$ after which cell viability was assessed.

\section{Cytotoxicity/cell viability assay}

Cytotoxicity/cell viability analysis was performed using the 3-(4, 5-dimethylthylthiazol-2-yl)-2, 5-diphenyltetrazolium bromide (MTT) method. $50 \mu$ of MTT tetrazolium salt (Sigma) dissolved in PBS at a concentration of $5 \mathrm{mg} /$ $\mathrm{ml}$ was added to each well at $70 \mathrm{~h}$ post treatment and incubated for $2 \mathrm{~h}$. The medium was then aspirated from 
Table 1 List of antiepileptic compounds used in this study and associated abbreviations, therapeutic plasma levels for epilepsy treatment, toxicity levels, and experimental dosing concentrations

\begin{tabular}{|c|c|c|c|c|}
\hline Drug name & $\begin{array}{l}\text { Drug } \\
\text { abbreviation }\end{array}$ & $\begin{array}{l}\text { Therapeutic } \\
\mu \mathrm{g} / \mathrm{ml}\end{array}$ & Toxic & $\begin{array}{l}\text { Dosing } \\
\text { concentrations } \\
\mu \mathrm{g} / \mathrm{ml}\end{array}$ \\
\hline Temozolomide & TMZ & $4-11$ & $\begin{array}{l}\text { Determined by } \\
\text { myelosupression/ } \\
\text { hepatotoxicity }\end{array}$ & $\begin{array}{l}0.04,0.4,4,10 \\
\quad 20,40\end{array}$ \\
\hline Dexamethasone & DEX & $2.6-18$ & Rat $\mathrm{LD}_{50} 3 \mathrm{gm} / \mathrm{kg}$ & $\begin{array}{l}0.008,0.08,0.8 \\
\quad 16,40\end{array}$ \\
\hline Valproic acid & VPA & $50-150$ & $450-850 \mu \mathrm{g} / \mathrm{ml}$ & $\begin{array}{l}10,100,250,500 \\
1000\end{array}$ \\
\hline Carbamazepine & $\mathrm{CBZ}$ & $4-12$ & $18-42.8 \mu \mathrm{g} / \mathrm{ml}$ & $1,2,4,8,16$ \\
\hline Ethosuximide & ESX & $40-160$ & $>150 \mu \mathrm{g} / \mathrm{ml}$ & $\begin{array}{l}10,20,40,80 \\
160\end{array}$ \\
\hline Gabapentin & GBP & $2-8.6$ & $40-100 \mathrm{~g}$ & $0.2,2,10,20$ \\
\hline Lamotrigine & LTG & $0.5-5.4$ & $13-62.4 \mu \mathrm{g} / \mathrm{ml}$ & $0.2,2,10,20$ \\
\hline Levetiracetam & LEV & $6.85-72$ & $60-400 \mu \mathrm{g} / \mathrm{ml}$ & $5,10,20,40,80$ \\
\hline Magnesium sulfate & $\mathrm{MgSO}_{4}$ & $240.83-421.45$ & $\begin{array}{l}\text { Plasma Mg level of } \\
\quad 4-12 \mathrm{mEq} / \mathrm{L}\end{array}$ & $\begin{array}{l}5.55,16.6,50 \\
150,450\end{array}$ \\
\hline Oxcarbazepine & $\mathrm{OXC}$ & $3-35$ & $30-40 \mu \mathrm{g} / \mathrm{ml}$ & $2.5,5,10,20,40$ \\
\hline $\begin{array}{l}\text { Licarbazepine (R-(-)-10-hydroxy-10,11-dihydro- } \\
\text { carbamazepine/monohydroxycarbamazepine) }\end{array}$ & $\begin{array}{r}\mathrm{R}-(-)- \\
\mathrm{MHC}\end{array}$ & $3-35$ & $30-40 \mu \mathrm{g} / \mathrm{ml}$ & $12.5,25,75$ \\
\hline $\begin{array}{l}\text { Eslicarbazepine (S- }(+)-10 \text {-hydroxy-10,11-dihydro- } \\
\text { carbamazepine/monohydroxycarbamazepine) }\end{array}$ & S-(+)-MHC & $3-35$ & $30-40 \mu \mathrm{g} / \mathrm{ml}$ & $12.5,25,75$ \\
\hline Phenytoin & PHT & $10-20$ & $20-40 \mu \mathrm{g} / \mathrm{ml}$ & $\begin{array}{l}0.04,0.4,4,20 \\
\quad 40\end{array}$ \\
\hline Primidone & PRM & $5-12$ & $40-80 \mu \mathrm{g} / \mathrm{ml}$ & $0.2,1,5,12.5,25$ \\
\hline Tiagabine & TGB & $0.04-0.55$ & $0.7-4.6 \mu \mathrm{g} / \mathrm{ml}$ & $\begin{array}{l}0.0008,0.008 \\
0.08,0.8\end{array}$ \\
\hline Topiramate & TPM & $2-19$ & $9.4-170 \mu \mathrm{g} / \mathrm{ml}$ & $0.2,2,10,20$ \\
\hline Vigabatrin & VBT & 5.3 & $60 \mathrm{~g}$ & $\begin{array}{l}0.04,0.4,4,20 \\
\quad 40\end{array}$ \\
\hline
\end{tabular}

each well and $200 \mu \mathrm{l}$ of DMSO was added to dissolve the formazan crystals. $150 \mu \mathrm{l}$ of the resulting solution was transferred to a 96-well plate and the absorbance of each well was obtained using a Tecan infinite M200 Pro plate reader at a wavelength of $570 \mathrm{~nm}$. Each experiment was replicated multiple times with similar results.

\section{Cell cycle analysis}

If growth inhibition reached $50 \%\left(\mathrm{IC}_{50}\right)$, cell cycle analysis was performed. Cells were trypsinized and harvested and fixed in $70 \%$ ethanol for at least $30 \mathrm{~min}$ at $4{ }^{\circ} \mathrm{C}$. After the removal of the alcoholic fixative, they were stained with a solution containing $50 \mu \mathrm{g} / \mathrm{ml}$ Propidium Iodide (PI) and $100 \mu \mathrm{g} / \mathrm{ml}$ RNase A (Sigma) for approximately $30 \mathrm{~min}$ at room temperature while being protected from light. Samples were then measured using flow cytometry (FACScans, Becton-Dickinson). Ten thousand events per sample were acquired and the data was analyzed using Cell Quest software (Becton-Dickinson).

\section{Statistical analysis}

The data were expressed as mean \pm standard deviation (SD). Statistical analysis was performed with Statistical Product and Service Solutions (SPSS) using analysis of variance (ANOVA). The criterion for statistical significance was taken as $\mathrm{p}<0.05$.

\section{Results}

\section{Cytotoxicity/cell viability}

Overall growth inhibition for all compounds and cell lines are shown in Fig. 1. Figure 2 depicts the maximum growth 
Fig. 1 Growth inhibition for all compounds and cell lines. a Growth inhibition for TMZ, VPA, and OXC, the three compounds that attained over $50 \%$ growth inhibition. b Growth inhibition for the OXC metabolites R- $(-\mathrm{MHC}$ and S-(+)-MHC. c Growth inhibition and enhancement for DEX, VBT, LEV, and ESX, the four compounds that displayed both growth inhibition and growth enhancement. d Growth inhibition for $\mathrm{MgSO}_{4}, \mathrm{CBZ}$, OHT, TPM, LTG, GBP, PRM, and TGB, the compounds that showed growth inhibition, but did not attain over $50 \%$ growth inhibition
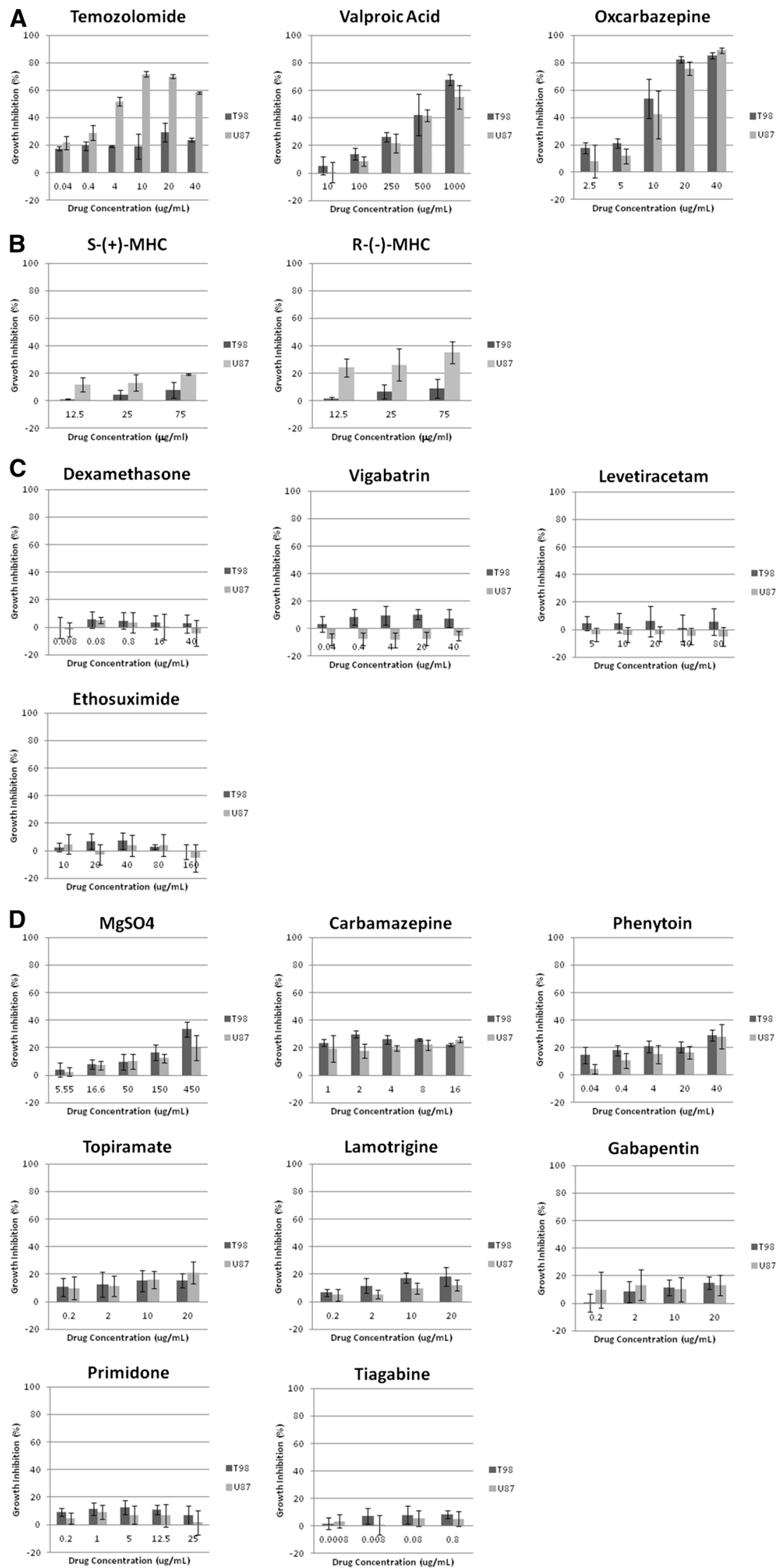
Fig. 2 a The 17 compounds ordered according to maximum percent of growth inhibition after treatment using the T98 cell line with a minimum of three replicates. b The 17 compounds ordered according to maximum percent of growth inhibition after treatment using the U87 cell line with a minimum of three replicates
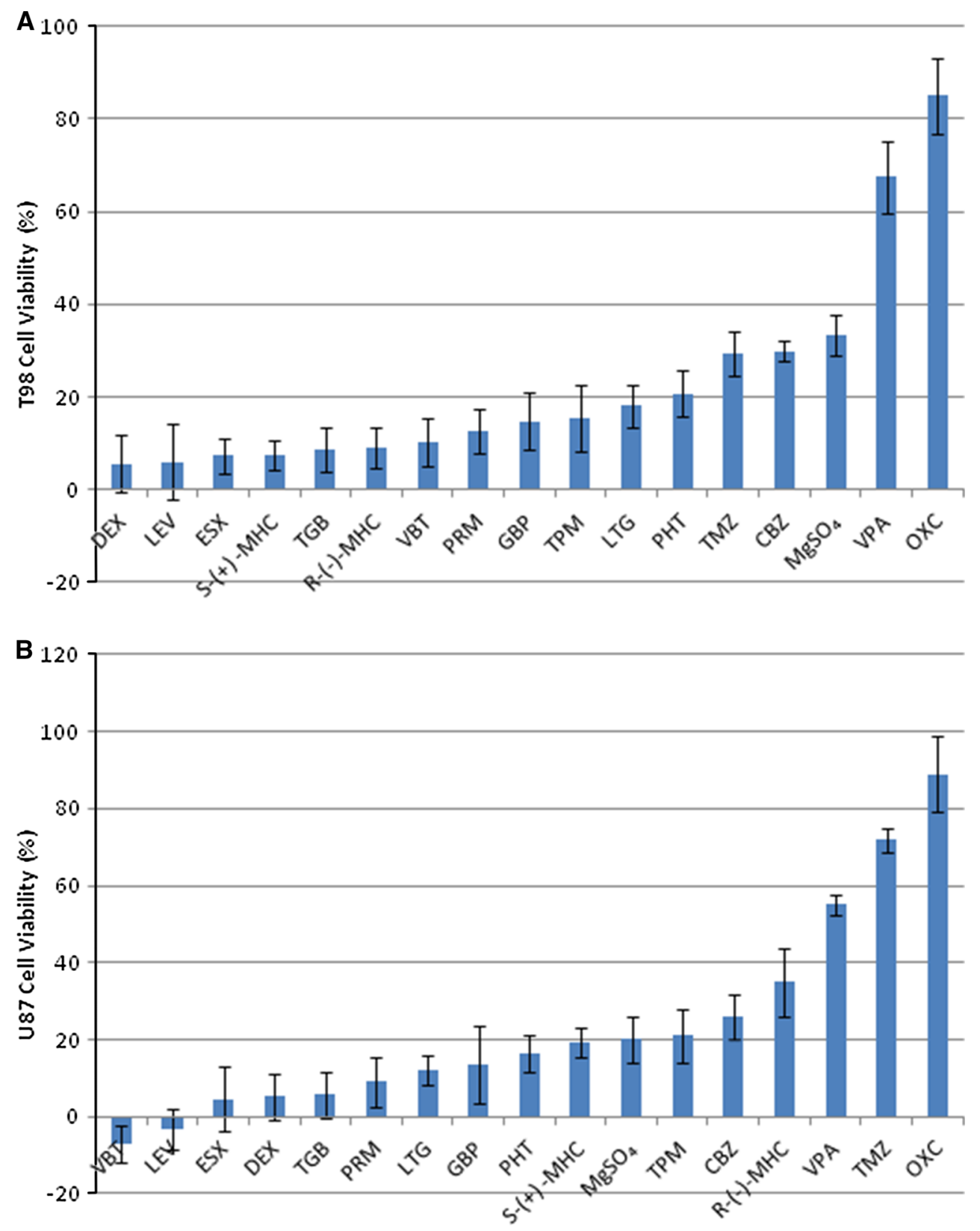

inhibition reached by each compound and can be separated into control compounds, non-effective compounds, and effective compounds, with effective compounds consisting of those that reached half maximal inhibitory concentration $\left(\mathrm{IC}_{50}\right)$ as shown in Table 2.

\section{Control group}

For TMZ, the growth inhibition for the T98G cell line (means and SDs) for each concentration was $17.6 \pm 1.5 \%$ $(0.04 \mu \mathrm{g} / \mathrm{ml}), \quad 19.4 \pm 3.1 \% \quad(0.4 \mu \mathrm{g} / \mathrm{ml}), \quad 19.2 \pm 0.7 \%$
Table $2 \mathrm{IC}_{50}$ of the effective compounds and compound metabolites screened with the U87 and T98 cell lines

\begin{tabular}{llcl}
\hline $\mathrm{IC}_{50}$ drug concentrations & & \\
\hline & Drug name & $\mathrm{U} 87 \mu \mathrm{g} / \mathrm{ml}$ & $\mathrm{T} 98$ \\
\hline AED & Oxcarbazepine & 12.35 & $9.45 \mu \mathrm{g} / \mathrm{ml}$ \\
AED & Valproic acid & 808.82 & $652.78 \mu \mathrm{g} / \mathrm{ml}$ \\
Positive CTL & Temozolomide & 3.4 & $*$
\end{tabular}

* $\mathrm{IC}_{50}$ was not reached in the T98 cell line using the highest drug concentration $(40 \mu \mathrm{g} / \mathrm{ml})$ of $\mathrm{TMZ}$ 
$(4 \mu \mathrm{g} / \mathrm{ml}), \quad 18.9 \pm 9.1 \% \quad(10 \mu \mathrm{g} / \mathrm{ml}), \quad 29.3 \pm 6.8 \%$ $(20 \mu \mathrm{g} / \mathrm{ml})$, and $23.8 \pm 1.4 \%(40 \mu \mathrm{g} / \mathrm{ml})$. For U-87 MG it was $21.8 \pm 4.8 \% \quad(0.04 \mu \mathrm{g} / \mathrm{ml}), 29.0 \pm 5.5 \% \quad(0.4 \mu \mathrm{g} /$ $\mathrm{ml}), 51.6 \pm 3.1 \%(4 \mu \mathrm{g} / \mathrm{ml}), 71.8 \pm 2.2 \% \quad(10 \mu \mathrm{g} / \mathrm{ml})$, $70.0 \pm 1.4 \%(20 \mu \mathrm{g} / \mathrm{ml})$, and $58.2 \pm 0.8 \%(40 \mu \mathrm{g} / \mathrm{ml})$. The T98 cell line was unable to reach $\mathrm{IC}_{50}$ at the concentrations used and only the $20 \mu \mathrm{g} / \mathrm{ml}$ concentration showed statistically significant growth inhibition ( $p$ value $=0.01)$. For U87, statistical significance was found at all concentrations ( $\mathrm{p}$ values of $0.012(0.4 \mu \mathrm{g} / \mathrm{ml})$ and $<0.001(4,10,20,40 \mu \mathrm{g} / \mathrm{ml}))$ and $\mathrm{IC}_{50}$ was calculated to be $3.4 \mu \mathrm{g} / \mathrm{ml}$.

For DEX, the growth inhibition for the T98G cell line for each concentration was $-0.3 \pm 7.5 \%(0.008 \mu \mathrm{g} / \mathrm{ml})$, $5.6 \pm 6.0 \%(0.08 \mu \mathrm{g} / \mathrm{ml}), 4.8 \pm 5.8 \%(0.8 \mu \mathrm{g} / \mathrm{ml}), 3.5 \pm$ $5.0 \%(16 \mu \mathrm{g} / \mathrm{ml})$, and $2.7 \pm 6.5 \%(40 \mu \mathrm{g} / \mathrm{ml})$. For U-87 MG it was $-1.7 \pm 5.1 \% \quad(0.008 \mu \mathrm{g} / \mathrm{ml}), \quad 5.3 \pm 2.4 \%$ $(0.08 \mu \mathrm{g} / \mathrm{ml}), \quad 3.5 \pm 7.4 \% \quad(0.8 \mu \mathrm{g} / \mathrm{ml}), \quad 0.3 \pm 9.2 \%$ $(16 \mu \mathrm{g} / \mathrm{ml})$, and $-4.2 \pm 9.6 \%(40 \mu \mathrm{g} / \mathrm{ml})$. While some concentrations resulted in a negative growth inhibition, it did not reach statistical significance.

\section{Non-effective group}

The growth inhibition for R-(-)-MHC in the T98G cell line (means and SDs) for each concentration was $1.3 \pm$ $1.2 \%(13 \mu \mathrm{g} / \mathrm{ml}), 6.5 \pm 5.3 \%(25 \mu \mathrm{g} / \mathrm{ml})$, and $8.9 \pm$ $6.7 \%(76 \mu \mathrm{g} / \mathrm{ml})$. For U-87 $\mathrm{MG}$ it was $24.0 \pm 6.8 \%$ $(13 \mu \mathrm{g} / \mathrm{ml}), 26.2 \pm 11.7 \%(25 \mu \mathrm{g} / \mathrm{ml})$, and $34.9 \pm 8.0 \%$ $(76 \mu \mathrm{g} / \mathrm{ml})$. The growth inhibition for $\mathrm{S}-(+)-\mathrm{MHC}$ in the T98G cell line for each concentration was $1.2 \pm 0.4 \%$ $(13 \mu \mathrm{g} / \mathrm{ml}), 4.2 \pm 3.6 \%(25 \mu \mathrm{g} / \mathrm{ml})$, and $7.6 \pm 5.6 \%$ $(76 \mu \mathrm{g} / \mathrm{ml})$. For U-87 MG it was $11.6 \pm 5.2 \%(13 \mu \mathrm{g} / \mathrm{ml})$, $13.0 \pm 6.0 \%(25 \mu \mathrm{g} / \mathrm{ml})$, and $19.3 \pm 0.7 \%(76 \mu \mathrm{g} / \mathrm{ml})$.

LTG, $\mathrm{MgSO}_{4}$, and PHT showed statistically significant growth inhibition in both cell lines, however, they did not reach $\mathrm{IC}_{50}$. Exposure to $\mathrm{CBZ}, \mathrm{ESX}$, and $\mathrm{GBP}$ resulted in statistically significant growth inhibition in the T98G cell line only, but also failed to reach $\mathrm{IC}_{50}$. The other antiepileptics, LEV, PRM, TGB, TPM, and VBT, used in this study failed to reach statistically significant growth inhibition. While VBT, LEV, ESX, and DEX did show some growth enhancement in the U87 and T98 cell lines, it was not statistically significant level.

\section{Effective group}

For VPA, the growth inhibition for the T98G cell line (means and SDs) for each concentration was $5.2 \pm 4.1 \%$ $(10 \mu \mathrm{g} / \mathrm{ml}), \quad 13.9 \pm 4.8 \% \quad(100 \mu \mathrm{g} / \mathrm{ml}), \quad 26.0 \pm 5.3 \%$ $(250 \mu \mathrm{g} / \mathrm{ml}), \quad 42.3 \pm 11.7 \%(500 \mu \mathrm{g} / \mathrm{ml})$, and $67.5 \pm$ $3.7 \%(1000 \mu \mathrm{g} / \mathrm{ml})$. For $\mathrm{U}-87 \mathrm{MG}$ it was $0.7 \pm 3.4 \%$ $(10 \mu \mathrm{g} / \mathrm{ml}), \quad 8.4 \pm 1.8 \% \quad(100 \mu \mathrm{g} / \mathrm{ml}), \quad 21.7 \pm 3.4 \%$
$(250 \mu \mathrm{g} / \mathrm{ml}), \quad 41.6 \pm 2.3 \% \quad(500 \mu \mathrm{g} / \mathrm{ml}), \quad$ and $55.2 \pm 3.3 \%(1000 \mu \mathrm{g} / \mathrm{ml})$. Statistically significant differences were found at the $100,250,500$, and $1000 \mu \mathrm{g} / \mathrm{ml}$ concentrations for the U87 cell lines ( $\mathrm{p}$ values of $<0.001$ ) and at the 250,500 , and $1000 \mu \mathrm{g} / \mathrm{ml}$ concentrations for the T98 cell lines ( $\mathrm{p}$ values of $<0.001$ ). $\mathrm{IC}_{50}$ was found at concentrations $>652.78 \mu \mathrm{g} / \mathrm{ml}$ for the T98 cell line and $>808.82 \mu \mathrm{g} / \mathrm{ml}$ for the U87 cell line.

For OXC, the growth inhibition for the T98G cell line for each concentration was $17.7 \pm 4.1 \%(2.5 \mu \mathrm{g} / \mathrm{ml})$, $21.1 \pm 3.6 \% \quad(5 \mu \mathrm{g} / \mathrm{ml}), \quad 53.6 \pm 14.2 \% \quad(10 \mu \mathrm{g} / \mathrm{ml})$, $82.2 \pm 2.3 \%(20 \mu \mathrm{g} / \mathrm{ml})$, and $85.0 \pm 2.3 \%(40 \mu \mathrm{g} / \mathrm{ml})$. For U-87 MG it was $8.0 \pm 11.8 \% \quad(2.5 \mu \mathrm{g} / \mathrm{ml})$, $11.7 \pm 5.3 \% \quad(5 \mu \mathrm{g} / \mathrm{ml}), \quad 42.1 \pm 17.6 \% \quad(10 \mu \mathrm{g} / \mathrm{ml})$, $75.7 \pm 4.7 \%(20 \mu \mathrm{g} / \mathrm{ml})$, and $89.0 \pm 1.8 \%(40 \mu \mathrm{g} / \mathrm{ml})$. Statistically significant differences were found at the 10 , 20 , and $40 \mu \mathrm{g} / \mathrm{ml}$ concentrations for the U87 and T98 cell lines ( $\mathrm{p}$ values of $<0.001$ ). $\mathrm{IC}_{50}$ was found at concentrations $>9.45 \mu \mathrm{g} / \mathrm{ml}$ for the T98 cell line and $>12.35 \mu \mathrm{g} / \mathrm{ml}$ for the U87 cell line.

\section{Overview of cytotoxicity/cell viability}

As seen in Fig. 2, the only VPA and OXC in the T98 cell line and VPA, TMZ, and OXC in the U87 cell line reached over $50 \%$ growth inhibition. In the T98 cell line, no compounds showed growth enhancement, 6 compounds (R-(-)-MHC, S-(+)-MHC, DEX, LEV, ESX, TGB) showed less than $10 \%$ growth inhibition, and 9 compounds (VBT, PRM, GBP, TPM, LTG, PHT, TMZ, CBZ, $\mathrm{MgSO}_{4}$ ) showed 10-35\% growth inhibition. In the U87 cell line, 2 compounds showed growth enhancement (VBT $7 \%$, LEV $3 \%$ ), 4 compounds (ESX, DEX, TGB, PRM) showed less than $10 \%$ growth inhibition, and 8 compounds (LGT, GBP, PHT, $\mathrm{MgSO}_{4}, \mathrm{TPM}, \mathrm{CBZ}, \mathrm{R}-(-)-$ MHC, S-(+)-MHC) showed 10-35\% growth inhibition. ESX and DEX also showed slight growth enhancement at high drug concentrations.

\section{Cell cycle analysis}

Cell cycle analysis was performed for TMZ, OXC, and VPA. The drug concentrations used for cell cycle analysis were $300 \mu \mathrm{M}$ for $\mathrm{TMZ}(\sim 60 \mu \mathrm{g} / \mathrm{ml})$ and $\mathrm{OXC}(\sim 80 \mu \mathrm{g} /$ $\mathrm{ml})$, and $10 \mathrm{mM}$ for VPA $(\sim 1500 \mu \mathrm{g} / \mathrm{ml})$. Flow cytometry was performed and the results given in Fig. 3 .

TMZ was shown to have minimal effect on the T98 cell line, but induced $\mathrm{G} 2 / \mathrm{M}$ arrest in the U87 cell line and increased SubG1 indicating apoptosis. OXC was shown to have greatly increased the SubG1 population in both T98 $(91.4 \%)$ and U87 (77.1\%). VPA was also shown to greatly increase the SubG1 population in T98 (88.1\%). Preliminary experiments using lower concentrations and 


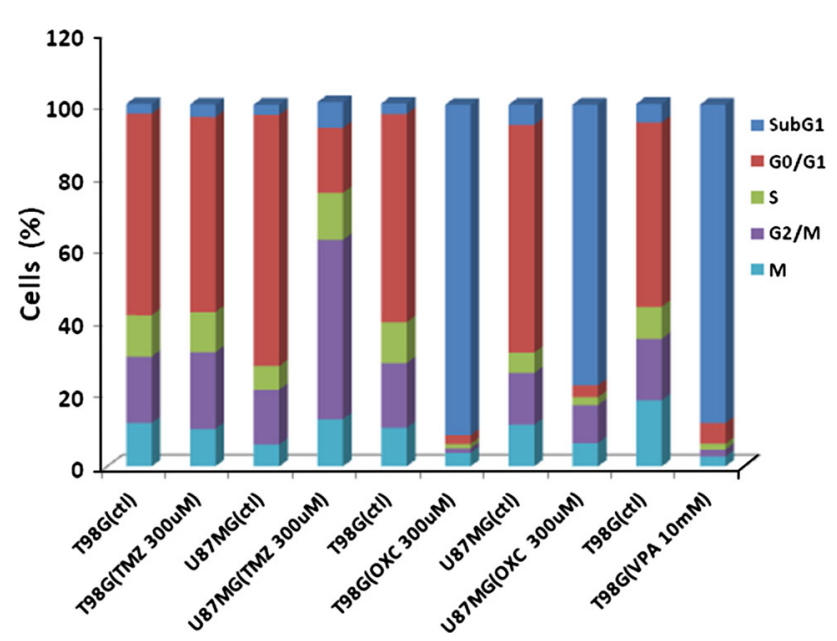

Fig. 3 Effect of TMZ, OXC, and VPA on cell cycle in two glioma cell lines

shorter incubation times for VPA and OXC indicate a possibility of $\mathrm{G} 2 / \mathrm{M}$ arrest at shorter incubation times and similar patterns in lower concentrations as long as $\mathrm{IC}_{50}$ is reached.

\section{Discussion}

In this study, we investigated three main areas, the effect of VPA alone on cancer cell growth, the concentration of VPA needed to affect cell growth, and the effects of various AEDs on cell growth.

\section{The effects of valproic acid}

Multiple studies have shown that the use of VPA in GBM results in cell growth inhibition in both the U-87 MG and the T98G cell lines. The drug concentration doses in these studies ranged from $\sim 35$ to $\sim 1500 \mu \mathrm{g} / \mathrm{ml}$. The data from these studies indicated that at $\sim 500 \mu \mathrm{g} / \mathrm{ml}$, a significant level of growth inhibition, approximately 40-60\%, was reached [39-41].

While the results of our study did find significant growth inhibition and apoptosis caused by VPA alone, the $\mathrm{IC}_{50}$ was found at concentrations that would be considered toxic when used in patients. The $\mathrm{IC}_{50}$ calculated for both cell lines were higher than that reported by others and far exceed the normal serum concentrations levels for the treatment of seizures $(50-100 \mathrm{ug} / \mathrm{ml})$. At therapeutic concentrations, VPA alone showed less than $20 \%$ growth inhibition. This indicates that VPA alone does not provide significant anti-cancer effects and the effects seen in our previous study on VPA in patients may be influenced by the fact that VPA was used in combination with TMZ, the chemotherapy of choice, or possibly radiation therapy (RT).

\section{The effects of other AEDs}

Of these other compounds used in this study, only OXC was shown to have significant inhibitory effects at what would be considered therapeutic levels for the treatment of epilepsy. The results for OXC showed that OXC was effective in inhibiting cell growth, was able to attain $\mathrm{IC}_{50}$, and induced possible G2M arrest and apoptosis. This information is similar to another study that also showed that OXC had possible anti-cancer effects in other cell lines though the concentrations used in that study far exceeded what would be considered therapeutic for epilepsy [42]. Further study is required to determine the exact mechanism behind the inhibitory effects of OXC. Due to the fact that $\mathrm{OXC}$ is a prodrug, the metabolites (R-(-)-MHC and $\mathrm{S}-(+)-\mathrm{MHC}$ were also assessed for cell growth inhibition. The metabolites did not reach $50 \%$ growth inhibition even at a concentration double the maximum accepted therapeutic plasma level for OXC metabolites. This discovery indicates that since $\mathrm{OXC}$ is quickly metabolized into $\mathrm{R}-(-)-\mathrm{MHC}$ and $\mathrm{S}-(+)-\mathrm{MHC}$ when OXC is taken orally, OXC may need a local delivery system to provide anticancer effects and bypass metabolism.

None of the other epileptics used in this study reached $\mathrm{IC}_{50} . \mathrm{MgSO}_{4}, \mathrm{PHT}, \mathrm{CBZ}, \mathrm{LTG}, \mathrm{GBP}, \mathrm{PRM}, \mathrm{TGB}$ and TPM showed overall growth inhibition in both cell lines. Even though CBZ and OXC have similar chemical structures, $\mathrm{CBZ}$ did not reach $\mathrm{IC}_{50}$ in our study and another study has shown that they are distinctly different drugs in their mode of action, metabolism, efficacy, and tolerability [43]. DEX and ESX showed slight growth inhibition in the T98 cell line, but growth enhancement at higher concentrations in the U87 cell line. LEV and VBT showed growth inhibition in the T98 cell line and growth enhancement in the U87 cell line at all concentrations. While the growth enhancement effects of ESX, LEV, and VBT failed to reach significance, the possible effects of these compounds should be taken under consideration when choosing epileptic therapy in patients with GBM.

\section{Impact on clinical practice}

While the survey of antiepileptic compounds was performed on glioblastoma cell lines and not in actual patients, there are still some aspects of this study that can be of benefit when considering the use of antiepileptics in the treatment of GBM patients.

While toxic doses of valproic acid are required to reach significant growth inhibition in this study, our previous 
study did find merit in the use of VPA in conjunction with standard therapy [25]. This finding also matches other studies that have found that VPA can be of benefit in some cancer patients though not in all cancer types [44-47]. While none of the current studies found that VPA alone improved outlook for cancer patients, VPA in conjunction with other therapies was found to possibly have benefit in some cancer types [25, 44-47]. While oral VPA monotherapy is impractical in GBM, local treatment using a wafer implanted after surgery may allow for higher local saturation to reach the needed concentration.

For oxcarbazepine, no clinical studies in patients have been reported. While oxcarbazepine did reach significant growth inhibition, which matches the information found by another study, it is a prodrug that is quickly metabolized [42]. While the parent drug, oxcarbazepine, has significant inhibitory effects, the metabolites of oxcarbazepine, licarbazepine and eslicarbazepine, did not reach significant growth inhibition indicating that orally given oxcarbazepine may not be clinically useful in treating GBM. The effectiveness of oxcarbazepine does indicate that it may be useful as a local treatment in the form of wafer implanted post surgery. Additional studies will be performed to explore this possibility.

Another important aspect of this study is the finding that some antiepileptics may have slight growth enhancement effects in GBM. While the growth enhancement was not significant, it is still important to note that the antiepileptics studied fell into two basic groups. The first group, consisting of VPA, OXC, R-(-)-MHC, S-(+)-MHC, $\mathrm{MgSO}_{4}$, PHT, CBZ, LTG, GBP, PRM, TGB and TPM, show growth inhibition of GBM cells indicating that the use of these compounds for the treatment of epilepsy in GBM patients is safe and has no negative impact on GBM patients. The second group, consisting of ESX, LEV, and VBT, however, showed minor growth enhancement. This finding, while not reaching significance, does call into question if these compounds should be avoided when deciding on prophylactic antiepileptic therapy or choosing antiepileptic therapy for newly diagnosed patients with GBM. With the multitude of options available for antiepileptic treatment, it may be useful to consider choosing antiepileptic compounds that demonstrate no growth enhancement at all over those that showed even slight growth enhancement.

\section{Conclusion}

Our results showed that TMZ, valproic acid, and oxcarbazepine significantly inhibited glioblastoma cell growth and that VPA and OXC may induce apoptosis or G2M arrest in glioblastoma cell lines. It was also demonstrated that OXC metabolites did not impact cell growth, therapeutic levels of VPA were not effective, and that toxic levels of VPA are needed to impact cell growth. These findings indicate that while VPA and OXC may not be useful as anti-cancer therapy when used as treatment for epilepsy, it is possible that both compounds may have efficacy when used as local treatment in the form of a wafer or local implant to bypass the issues of toxicity and metabolism. The other antiepileptic drugs screened did not show significant growth inhibition or enhancement, though the compounds that enhance cell growth may need further consideration before use in GBM patients. Future studies are needed to examine the effectiveness of AEDs when given in combination with standard GBM therapy, to define the mechanism behind OXC's effectiveness, and to explore the possibility of using VPA or OXC as local treatment. Furthering our understanding of AEDs used in the treatment of GBM patients can lead to the development of better clinical therapy guidelines.

Funding We would also like to thank Chang Gung Memorial Hospital for funding this study (CMRPG3B1081 and CMRPG3C1261).

\section{Compliance with ethical standards}

Conflict of interest None.

Open Access This article is distributed under the terms of the Creative Commons Attribution 4.0 International License (http://creati vecommons.org/licenses/by/4.0/), which permits unrestricted use, distribution, and reproduction in any medium, provided you give appropriate credit to the original author(s) and the source, provide a link to the Creative Commons license, and indicate if changes were made.

\section{References}

1. CBTRUS (2011) CBTRUS statistical report: primary brain and central nervous system tumors diagnosed in the United States in 2004-2007. Source: Central Brain Tumor Registry of the United States, Hinsdale www.cbtrus.org. Accessed 13 Aug 2012

2. DeAngelis LM (2001) Brain tumors. N Engl J Med 344(2): 114-123

3. Fisher JL, Schwartzbaum JA, Wrensch M, Wiemels JL (2007) Epidemiology of brain tumors. Neurol Clin 25:867-890

4. Rowland LP, Pedley TA (eds) (2010) Merritt's neurology, 12th edn. Lippincott, Williams, \& Wilkins, Philadelphia

5. Smith KC (2010) The management of seizures in brain tumor patients. J Neurosci Nurs 1:28-37

6. Chabner BC (ed) (2008) Harrison's manual of oncology, 1st edn. McGraw-Hill Companies Inc., New York

7. Chamberlain MC, Kormanik PA (1998) Practical guidelines for the treatment of malignant gliomas. West J Med 169:114-120

8. Grossman SA, Batara JF (2004) Current management of glioblastoma multiforme. Semin Oncol 31:635-644

9. Longo DL, Fauci AS, Kasper DL, Hauser SL, Jameson JL, Loscalzo J (eds) (2012) Harrison's principles of internal medicine, 18th edn. McGraw-Hill Companies Inc., New York 
10. National Comprehensive Cancer Network (2011) Central nervous system cancers. NCCN clinical practice guidelines in oncology version 2

11. Samuels MA, Ropper AH (eds) (2010) Samuels's manual of neurologic therapeutics, 8th edn. Lippincott, Williams, \& Wilkins, Philadelphia

12. Stupp R, Tonn JC, Brada M, Pentheroudakis G (2010) Highgrade malignant glioma: ESMO clinical practice guidelines for diagnosis Treatment and Follow-up. Ann Oncol 21(Suppl 5):v190-v193

13. Wen PY, Kesari S (2008) Malignant gliomas in adults. N Engl J Med 359:492-507

14. Wen PY, Schiff D, Kesari S, Drappatz J, Gigas DC, Doherty L (2006) Medical management of patients with brain tumors. J Neurooncol 80:313-332

15. Kargiotis O, Markoula S, Kyritsis AP (2001) Epilepsy in the cancer patient. Cancer Chemother Pharmacol 67:489-501

16. Van Breemen MSM, Wilms EB, Vecht CJ (2007) Epilepsy in patients with brain tumours: epidemiology, mechanisms, and management. Lancet Neurol 6:421-430

17. Sperling MR, Ko J (2006) Seizures and brain tumors. Semin Oncol 33:333-341

18. Blaheta RA, Cinatl J Jr (2002) Anti-tumor mechanisms of valproate: a novel role for an old drug. Med Res Rev 22(5):492-511

19. Drappatz J, Schiff D, Kesari S, Norden AD, Wen PY (2007) Medical management of brain tumor patients. Neurol Clin 25:1035-1071

20. Michelucci R (2006) Optimizing therapy of seizures in neurosurgery. Neurology 67(Suppl 4):S14-S18

21. Rosati A, Tomassini A, Pollo B, Ambrosi C, Schwarz A, Padovani A et al (2009) Epilepsy in cerebral glioma: timing of appearance and histological correlations. J Neurooncol 93:395-400

22. Rossetti AO, Stupp R (2010) Epilepsy in brain tumor patients. Curr Opin Neurol 23:603-609

23. Schaller B, Ruegg SJ (2003) Brain tumor and seizures: pathophysiology and its implications for treatment revisited. Epilepsia 44(9):1223-1232

24. Vecht CJ, Van Breemen M (2006) Optimizing therapy of seizures in patients with brain tumors. Neurology 67(Suppl 4):S10-S13

25. Tsai HC, Wei KC, Tsai CN, Huang YC, Chen PY, Chen SM et al (2012) Effect of valproic acid on the outcome of glioblastoma multiforme. Br J Neurosurg 26(3):347-354

26. De Salvo M, Maresca G, D'Angano I, Marchese R, Stigliano A, Gagliassi R et al (2011) Temozolomide induced c-Myc-mediated apoptosis via akt signaling in mgmt expressing glioblastoma cells. Int J Radiat Biol 87(5):518-533

27. Kanzawa T, Germano IM, Komata T, Ito H, Kondo Y, Kondo S (2004) Role of autophagy in temozolomide-induced cytotoxicity for malignant glioma cells. Cell Death Differ 11:448-457

28. Zhang WB, Wang Z, Shu F, Jin YH, Liu HY, Wang QJ et al (2010) Activation of AMP-activated protein kinase by temozolomide contributes to apoptosis in glioblastoma cells via p53 activation and mTORC1 inhibition. J Biol Chem 285(52):4046140471

29. Goellner EM, Grimme B, Brown AR, Lin YC, Wang XH, Sugrue $\mathrm{KF}$ et al (2011) Overcoming temozolomide resistance in glioblastoma via dual inhibition of nad $^{+}$biosynthesis and base excision repair. Cancer Res 71:2308-2317

30. Das A, Banik NL, Ray SK (2008) Modulatory effect of acetazolomide and dexamethasone on temozolomide mediated apoptosis in human glioblastoma T98G and U87MG cells. Cancer Invest 26:352-358
31. Moroz MA, Huang R, Kochetkov T, Shi W, Thaler H, de Stanchina $\mathrm{E}$ et al (2011) Comparison of corticotropin-releasing factor, dexamethasone, and temozolomide: treatment efficacy and toxicity in U87 and C6 intracranial gliomas. Clin Cancer Res 17:3282-3292

32. Toutain PL (2002) Pharmacokinetic/pharmacodynamic integration in drug development and dosage-regimen optimization for veterinary medicine. AAPS PharmSci 4(4):1-29

33. de Lange ECM, Ravenstijn PGM, Groenendaal D, van Steeg TJ (2005) Towards the prediction of cns drug-effect profiles in physiological and pathological conditions using microdialysis and mechanism-based pharmacokinetic-pharmacodynamic modeling. AAPS J 7(3):E532-E542

34. Johannessen SI, Tomson T (2006) Pharmacokinetic variability of newer antiepileptic drugs. When is monitoring needed? Clin Pharmacokinet 45(11):1061-1075

35. Micromedex ${ }^{\circledR}$ Healthcare Series [Internet database] Greenwood Village, Colorado: Thomson Reuters (Healthcare) Inc. Updated periodically

36. Brunton LL, Chabner BA, Knollmann BC (2011) Goodman \& Gilman's the pharmacological basis of therapeutics, 12th edn. McGraw-Hill Companies Inc, New York

37. DiPiro JT, Talbert RL, Yee GC, Matzke GR, Wells BG, Posey LM (eds) (2011) Pharmacotherapy: a pathophysiologic approach, 8th edn. McGraw-Hill Companies Inc., New York

38. Katzung BG, Masters SB, Trevor AJ (eds) (2012) Basic \& clinical pharmacology, 12th edn. McGraw-Hill Companies Inc., New York

39. Das CM, Aguilera D, Vasquez H, Prasad P, Zhang M, Wolff JE et al (2007) Valproic acid induces p21 and topoisomerase-II $(\alpha / \beta)$ expression and synergistically enhances etoposide cytotoxicity in human glioblastoma cell lines. J Neurooncol 85:159-170

40. Fu J, Shao CJ, Chen FR, Ng HK, Chen ZP (2010) Autophagy induced by valproic acid is associated with oxidative stress in glioma cell lines. Neuro-Oncology 12(4):328-340

41. Wagner S, van Gool S, Hau P, Pietsch T, Peters O, Wolff J (2009) Valproic acid as a potent substance for increasing efficacy of topoisomerase i inhibitors. Turk J Cancer 39(5):104-109

42. El Sharkawi FZ, El Shemy HA, Khaled HM (2014) Possible anticancer activity of rosuvastatine, doxazosin, repaglinide, and oxcarbazepin. Asian Pac J Cancer Prev 15:199-203

43. Schmidt D, Elger CE (2004) What in the evidence that oxcarbazepine and carbamazepine are distinctly different antiepileptic drugs? Epilepsy Behav 5:627-635

44. Blaheta RA, Michaelis M, Driever PH, Cinatl J Jr (2005) Evolving anticancer drug valproic acid: insights in the mechanism and clinical studies. Med Res Rev 25(4):383-397

45. Sharma S, Symanowski J, Wong B, Dino P, Manno P, Vogelzang N (2008) A phase II clinical trail of oral valroic acid in patients with castration-resistant prostate cancers using an intensive biomarker sampling strategy. Transl Oncol 1(3):141-147

46. Atmaca A, Al-Batran SE, Maurer A, Neumann A, Heinzel T, Hentsch B, Schwarz SE, Hovelmann S, Gottlicher M, Knuth A, Jager E (2007) Valproic Acid (VPA) in patients with refractory advanced cancer: a dose escalating phase I clinical trial. Br J Cancer 97:177-182

47. Bauman J, Shaheen M, Verschraegen CF, Belinsky SA, Fekrazad MH, Lee FC, Rabinowitz I, Ravindranathan M, Jones DV Jr (2014) A phase I protocol of hydralazine and valproic acid in advanced previously treated solid cancers. Transl Oncol 7(3): 349-354 